Jour. Korean Earth Science Society, v. 33, no. 6, p. 519-533, October 2012

http://dx.doi.org/10.5467/JKESS.2012.33.6.519

\title{
Late Neogene and Quaternary Vertical Motions in the Otway Coast, Southeast Australia (I): Development and Geochronology of Quaternary Marine Terraces \\ Jaeryul Shin* \\ Department of Geography, Kyungpook National University, Daegu 701-702, Korea
}

\section{호주 남동부 Otway 해안의 후기 신제3기 및 제4기 융기 운동(l): 제4기 해안단구 발달 및 지층서}

\author{
신 재 열* \\ 경북대학교 지리학과, 702-701, 대구광역시 북구 대학로 80
}

\begin{abstract}
This study investigates a neotectonic context of the past $5 \mathrm{Ma}$ for the Otway Ranges along the southern Victoria coast, SE Australia by evaluating the distribution and development of marine terraces along the mountainous coastal area. Uplift rate derived from low terrace deposits using OSL dating method is determined to evaluate the extent to which mild intraplate tectonism has the capability to influence the geomorphic evolution of continental interiors. This study also investigates the stratigraphic relationship between Quaternary marine terraces and Pliocene strandlines, which suggests a change of tectonic activity in the Late Neogene. The intensified tectonic response is well addressed in terms of an increase of the Australian intraplate stress level due to the change of relative motion and increased forces in the boundary between the Australian and Pacific plate.
\end{abstract}

Keywords: Quaternary marine terrace, OSL dating, Pliocene shoreline, tectonic activity, SE Australia

요 약: 본 연구는 호주 남동부 Victoria 남부 해안을 따라 발달하고 있는 Otway 산맥 일대에서 지난 $5 \mathrm{Ma}$ 동안의 신기 지체구조 운동의 성격을 해안 산악 지역을 따라 분포하고 있는 해안단구의 발달상을 통해 밝히고 있다. OSL 연대 측정 으로부터 얻은 저위 해안단구면의 융기율은 판 내부 구조운동의 영향이 현생 지형 발달에 미치는 결과를 명확히 보여주 고 있다. 또한 본 연구는 제4기 해안단구와 플라이오세 고해수준 기록 간의 층서적 관계를 통해 후기 신제 3 기 이후에 나타나는 지구조 운동의 변화적 속성을 밝히고 있다. 이와 같은 후기 신제3기 이후 가속화된 지구조 운동 반응은 호주태평양판의 이동성의 변화와 이에 따른 경계 응력의 증가가 대륙 내부 응력 수준에도 영향을 미친 결과로 이해된다.

주요어: 제4기 해안단구, OSL 연대측정, Pliocene 고해수준, 지구조 활동성, 호주 남동부

\section{Introduction}

One of the most tectonically active regions in Southeast Australia is the Otway Ranges in the southern Victoria. This is reflected by its geomorphic features such as its rugged, incised coastal mountains. Significant indications of the late Neogene tectonics in

*Corresponding author: jaeryul.shin@gmail.com Tel: +82-53-950-5227

Fax: +82-53-950-6227 the region are well illustrated by a preserved Pliocene strandplain (Hanson Plain Sand) deposited broadly across the western Victoria up into the northwestern flanks of the ranges (Fig. 1). These Pliocene ENEtrending strata are slightly folded about an axis parallel to the ranges, and are displaced by faults in many localities in the region bordering the ranges (Shoemaker and Uhlherr, 1999; Sandiford, 2003a). In places these strandlines are elevated as high as $240 \mathrm{~m}$ above sea level with individual strandlines having as much as $140 \mathrm{~m}$ of relief. 


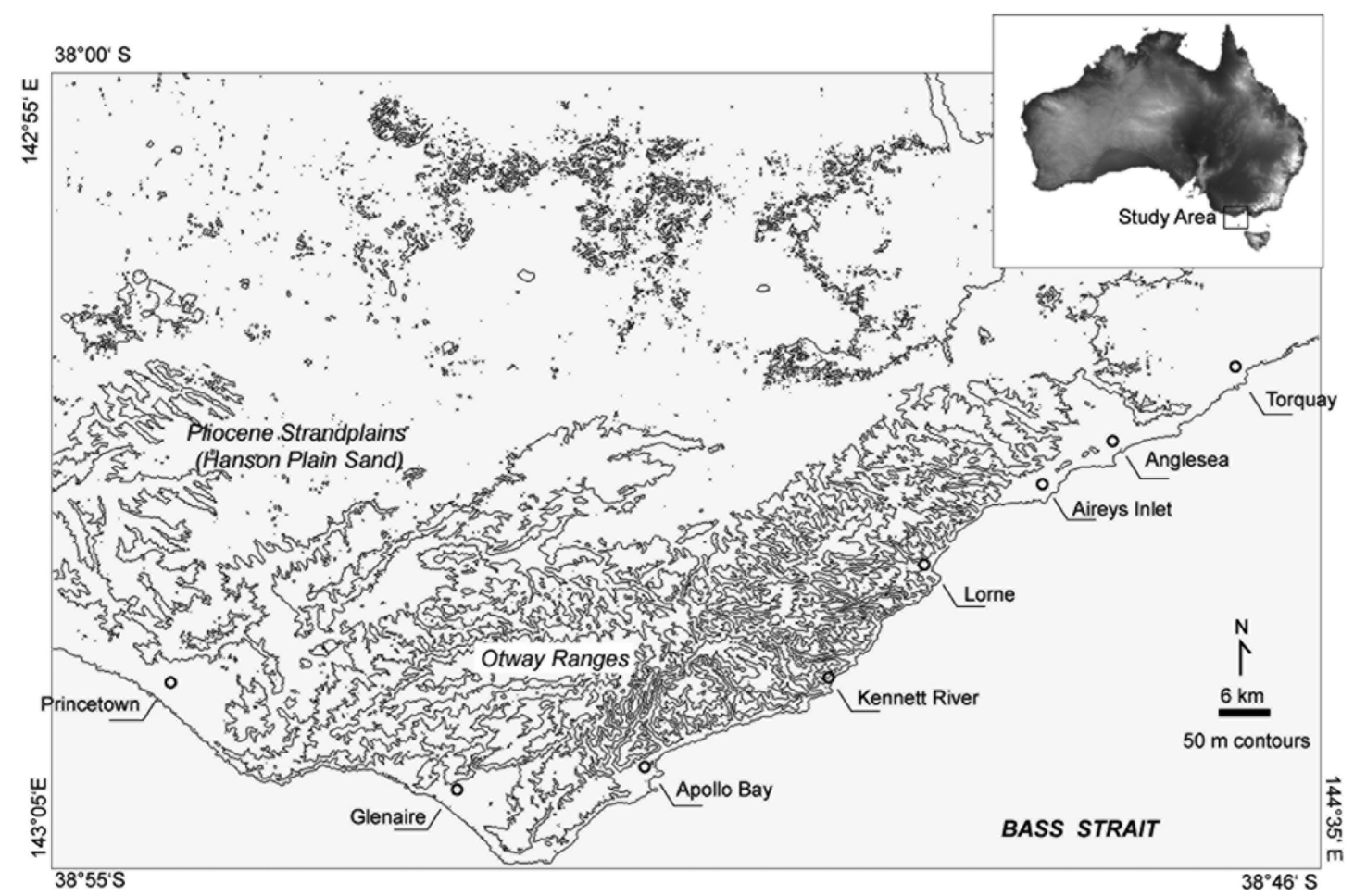

Fig. 1. Study area with $50 \mathrm{~m}$ contours showing the Otway Ranges and the southern coast. The centre of the Newer Volcanism (Late Pliocene to Quaternary) is located in the north farther. The uplift increases away from the centre.

The ongoing deformation in the Otway Ranges correlates with mild tectonic activity across a much broader region in Southern Australia. For example, in South Australia, the Flinders Range is bounded by a set of scarps associated with active bounding faults with cumulative late Neogene displaces in excess of 100 meters (Sandiford, 2003b; Quigley et al., 2006). Another more subtle evidence for young tectonism occurs across the extensive Miocene-Pliocene Nullarbor Plain along the central southern margin of Australia. The elevations of these Miocene shorelines along the northern inland bordered the plain drop systematically eastwards from 200 to $30 \mathrm{~m}$ above sea level, implying a differential vertical motion in excess of $150 \mathrm{~m}$ over a $\sim 1000 \mathrm{kms}$ (James et al., 2006). The various modes and possible mechanisms for the Late Cenozoic deformations in South and Southeast Australia have been discussed by Celerier et al. (2005), Demidjuk et al. (2007) and Quigley et al. (2006), but remain enigmatic.
It is clear from these observations that elevation of Neogene marine shorelines and associated geomorphic features are crucial to evaluating the tectonic activity in Southern Australia. The preservation of marine terraces above present sea level signifies both the sea level stand at the formation time and subsequent tectonic uplift. With increasing information on past sea levels, marine terraces have increasingly used to evaluate rates of tectonic controls in intraplate settings (Murray-Wallace, 2002; Claessens et al., 2009). In this study geographic distributions and vertical elevations of the marine terraces in the southern coast of the Otway Ranges, SE Australia have been mapped, and quantitative uplift rates have been established using Optically Stimulated Luminescence (OSL) dating method from overlying terrace deposits. The relationship between tectonic uplift and geophysical analysis of gravity anomalies and the in-situ stress fields will be documented in the following paper in order to understand the nature and possible mechanism for the 
Table 1. Distribution of Otway marine terraces and the chronology

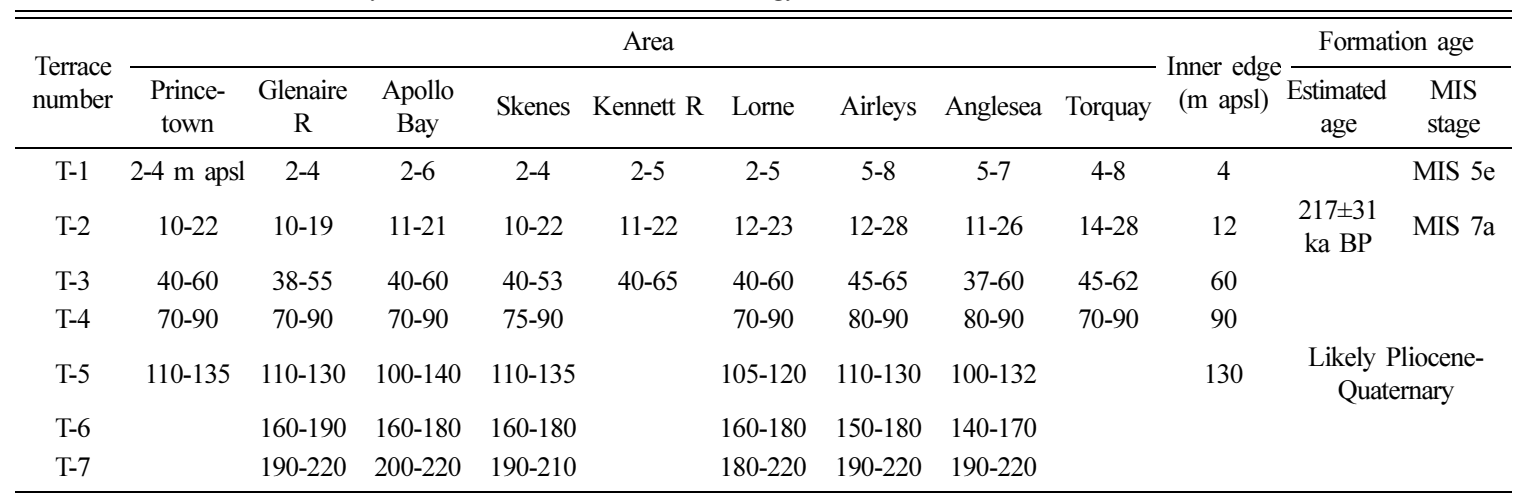

neotectonic movements associated with the Otway Ranges in Southeast Australia.

\section{Coastal Geomorphology and Preservation of Marine Terraces}

The investigated areas in this study include the southern coast of the Otway Ranges (the Otway coast) extending from Torquay in the east to Port Campbell in the west over a distance of $\sim 160 \mathrm{~km}$ (Fig. 1). This coast displays extensively steepened sea bluffs of Tertiary marine and calcareous fluvio-deltaic successions. Yet, there has been little recognition of coastal terrace sequences in this region. Only one exception is the study of Gippsland region near Cape Liptrap, SE Australia by Gardner et al. (2008).

Survival of marine terraces after emergence is largely controlled by subsequent erosional and aeolian processes (Caputo, 2007; Claessens et al., 2009). Much of the southern Australian coastline experiences relatively high wave energy conditions with $>20 \%$ of waves over $2.5 \mathrm{~m}$ high for at least two quarters of the year (Davies, 1986). In addition, extensive eolianite successions have developed along the southern Australian coasts throughout the late Quaternary associated with regional aridity where evaporation far exceeds precipitation (Brooke, 2001). Both features tend to limit preservation of marine terraces to particularly favourable sites. In addition, some major high sea stands during the Quaternary can be only recorded as a flight of terraces, especially in relatively slow uplifting regions. Coastal processes associated with younger high sea stand largely tend to obliterate or completely destroy evidence of older terraces whose relative altitude is lower than $10 \mathrm{~m}$ (Caputo, 2007). This may account for poor preservation of the early Quaternary marine terraces and a disconformable relationship between the Pliocene and Quaternary marine deposits in southern Victoria (Wallace et al., 2005).

\section{Distribution of Marine Terraces}

Seven distinct flights of terraces elevated up to 220 $\mathrm{m}$ above present sea level (apsl) have been mapped along the Otway coast, and are designated T-1 to T-7 from the youngest to oldest (Table 1, Fig. 2, Fig. 3). Positioning and altitude measurement were estimated using 1:25,000 scaled maps and calibrated GPS data. Vertical terrace profiles with OSL sample locations are illustrated in Fig. 4.

T-1

The T-1 terrace is the lowest level, ranging in elevation from 2 to $8 \mathrm{~m}$ apsl. The terraces are largely preserved in specific sites. In areas dominated by longshore transport of coastal sediments such as Torquay, Lorne and Apollo Bay, the T-1 is preserved as a small strandplain deposited in the inner bay. In headlands, this terrace is typically expressed as a shore platform most clearly observed in Sugarloaf and Skenes Creek. T-1 terrace is also observed as a 

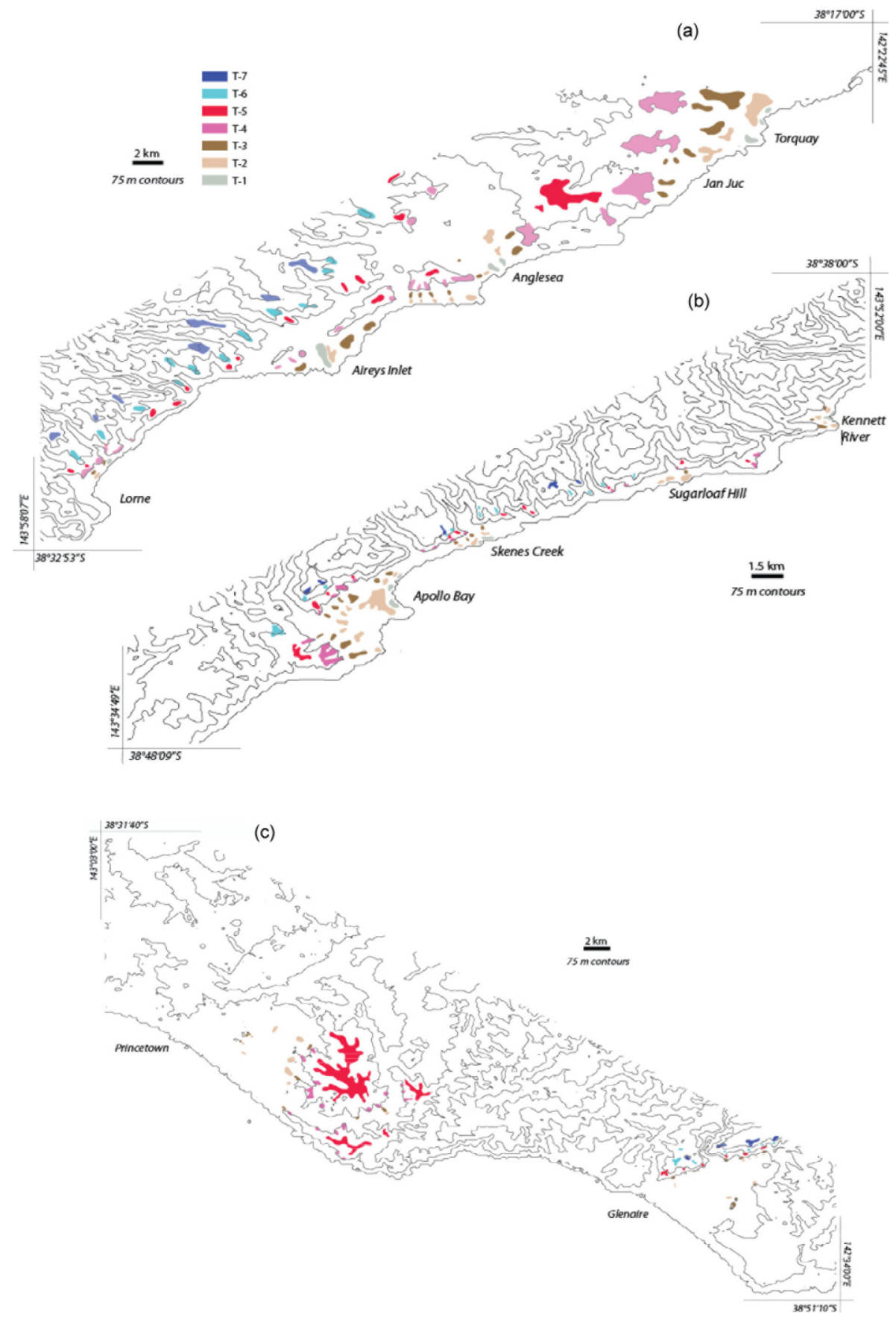

Fig. 2. Maps of marine terrace distribution along the Otway coasts. (a) The eastern section from Torquay to Lorne, (b) The central section from Kennett River to Apollo Bay, and (c) The western section from Glenaire to Princetown.

thalassostatic terrace along Anglesea River in Anglesea, Painkalac and Distillery creeks in Aireys Inlet, Aire River in Glenaire, Johanna River in Johanna, and in Gellibrand River in Princetown. The areas are characterised as a large estuary or a backbarrier lagoon protected from sea-wave erosion by barrier spits and embayment. 


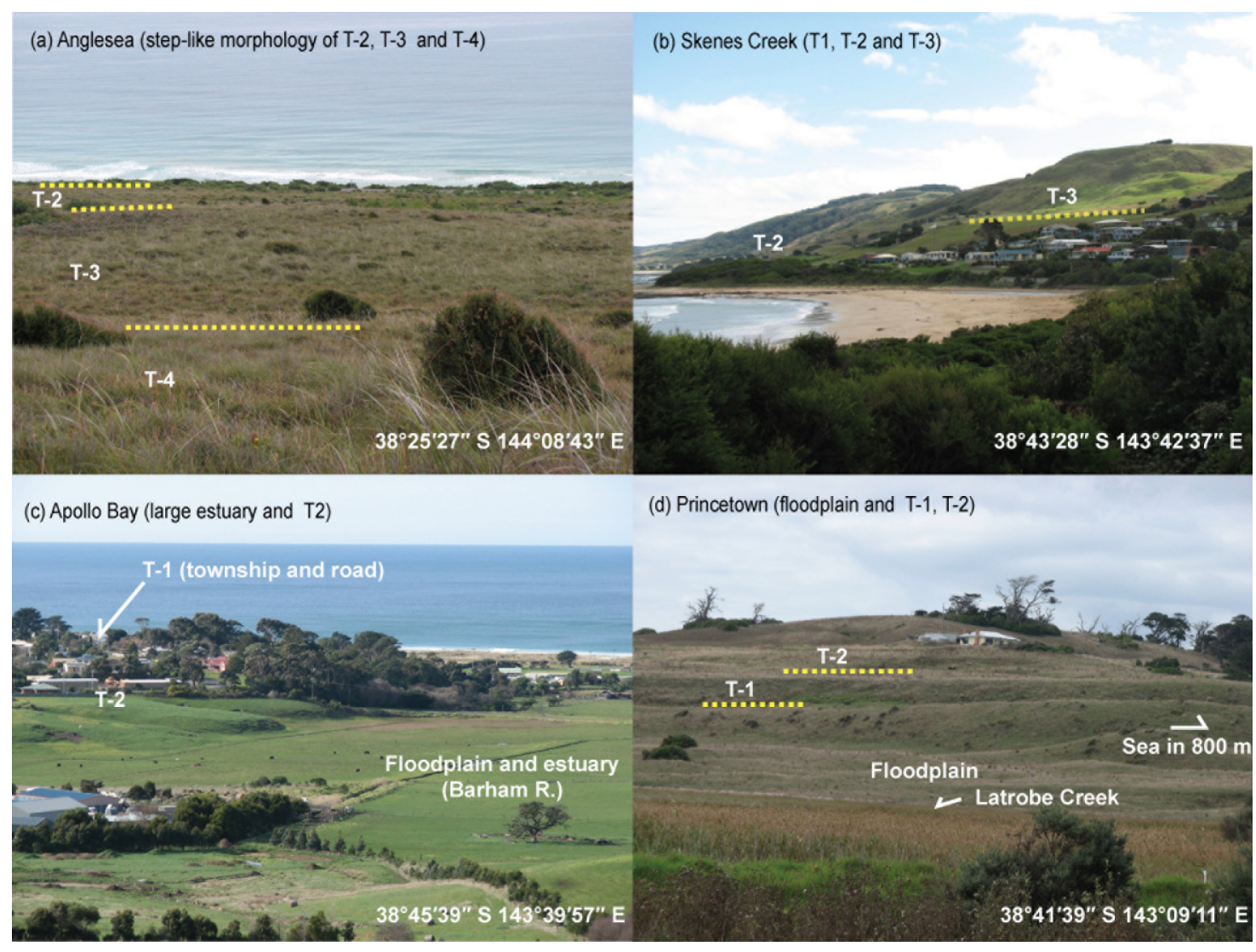

Fig. 3. Field photographs from Otway marine terraces in Anglesea (a), Skenes Creek (b), Apollo Bay (c), and Princetown (d).

\section{$\mathrm{T}-2$}

$\mathrm{T}-2$ terraces are the most extensive and ubiquitous that the elevations vary from 10 to $28 \mathrm{~m}$ apsl. This terrace is best exposed in Torquay and Apollo Bay with a length of several hundred meters where planar surfaces with very low relief are exceptionally preserved. Exposed outcrops have been found in Kennett River, Apollo Bay and Gellibrand Lower that are mainly composed of sands, granules and well-rounded pebbles with horizontal or slightly seaward beddings. Granules and pebbles are well sorted, and seaward imbrications are generally prominent. In particular, the sedimentary units in Kennett River and Apollo Bay are deposited on the planar surface strata with centimeter-scale relief, suggesting that the planar surfaces were formed by sea wave actions and subsequent weathering processes. In places where a bedrock surface is exposed, the uppermost of bedrock strata is, in general, deeply weathered and incised by streams. The elevations in the easternmost section of the investigated areas including Torquay, Anglesea and Aireys Inlet are a few meters higher than those to the west (Table 1). As this difference in elevation is observed on both the T-1 and the T-2 terrace, but not recognised above T-3 terraces, it is likely that the higher elevation in $\mathrm{T}-1$ and $\mathrm{T}-2$ in the easternmost areas reflects seaward depositional thickening, implying Quaternary high sea stands have likely contributed to thicker sediments aprons on terraces during their terrace formation periods. The eastern section is a locality characterised by relative depocenter of Tertiary marine sediments of clayey quartz sand, sandy clay and quartz gravel.

$\mathrm{T}-3$

T-3 terraces occur as relatively small remnants 

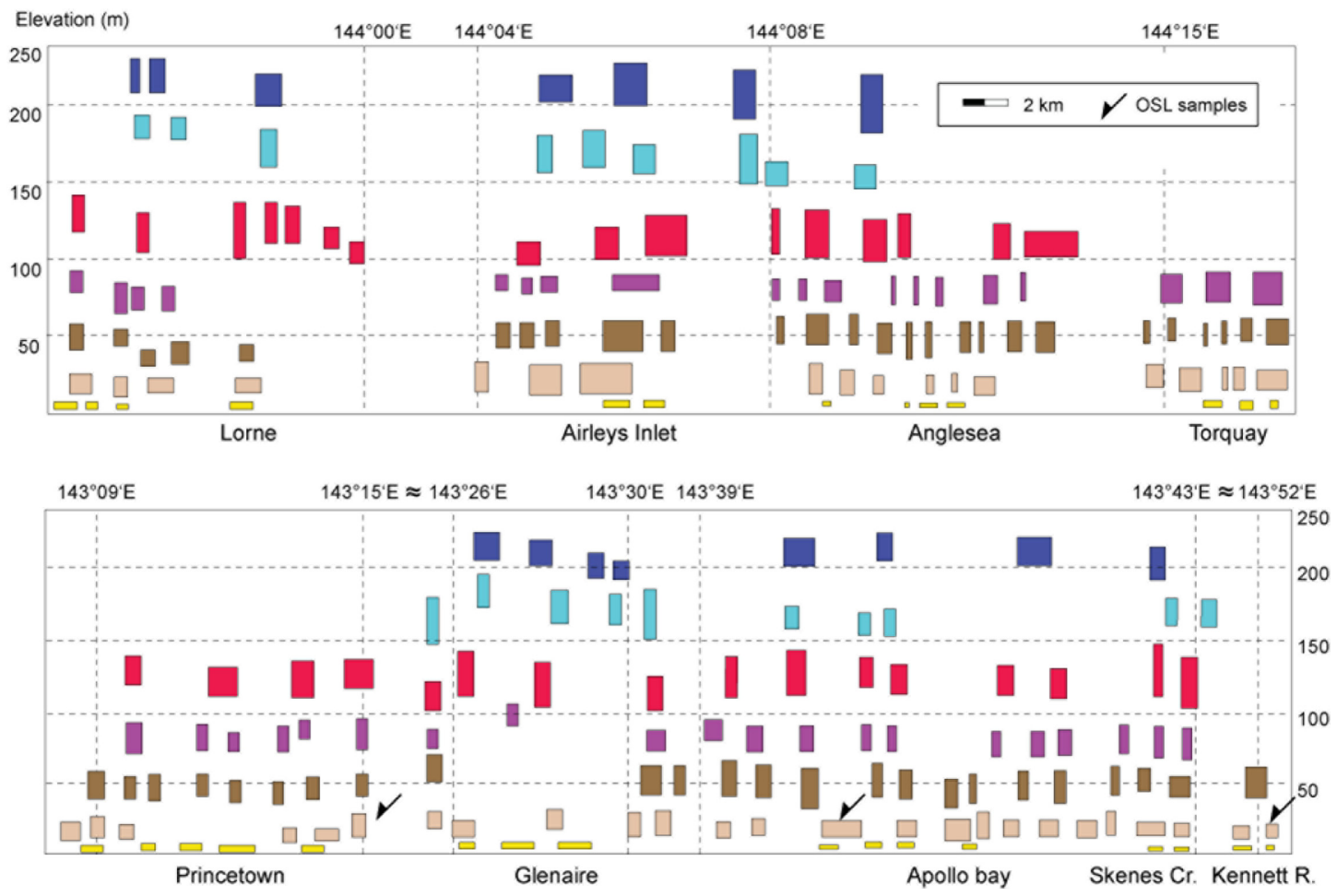

Fig. 4. Vertical terrace profiles with OSL sample locations.

gently sloping seaward at $40-65 \mathrm{~m}$ apsl. The T-3 terrace and higher terraces (T-4 to T-7) are commonly dissected and sloped elongated towards the T-1- and T-2 terraces: a feature that can be contributed to time for stream incisions. Extensive colluvial and aeolian deposits often cover the T-3 terraces for example, in Aireys Inlet and Apollo Bay. In Torquay, T-3 terraces are covered by thick $(\sim 2 \mathrm{~m})$, fine to coarse-grained, quartzite sands with granules and pebbles. This terrace is best preserved in the southern flank of Mt. Ingoldsby along the coast between Anglesea and Aireys Inlet, but the surface strata are not well exposed, and are often colluviated. The surficial sediments consist of well-rounded pebbles and cobbles with fine sand and clay.

\section{T-4}

The T-4 terrace is the most extensive terrace set ranging in elevation from 70 to $90 \mathrm{~m}$ apsl. The terrace tread is exceptionally flat, and probably has been deflated by aeolian activity. The best outcrop has found in Airley Inlet $\left(38^{\circ} 27^{\prime} 00^{\prime \prime} \mathrm{S}, 144^{\circ} 06^{\prime} 00^{\prime \prime} \mathrm{E}\right)$, which consists of quartzite pebbles and granules with the matrix of fine to coarse sand. Although quartzite pebbles and granules are likely to be derived from local basements, relatively fresh sands and granules are distinct from basement geology. The exposed bedrock surfaces have been extensively mechanically weathered.

\section{$\mathrm{T}-5, \mathrm{~T}-6$ and $\mathrm{T}-7$}

Terraces from the $\mathrm{T}-5$ to the $\mathrm{T}-7$ occur as well defined, planar treads separated by distinct risers, although no marine deposits have been found. The T5 terrace is elevated at $100-130 \mathrm{~m}$ apsl, and the T-6 and the T-7 terrace range at $140-180 \mathrm{~m}$ and at 190 $220 \mathrm{~m}$ apsl, respectively. The T-5 to T-7 terraces are expressed as the most typical step-like morphology with sub-planar surfaces, and the altitudes are uniform over the entire investigated areas. In addition, geomorphic indications such as uniform altitudes, elongated seaward sloping aspects and occurrence 

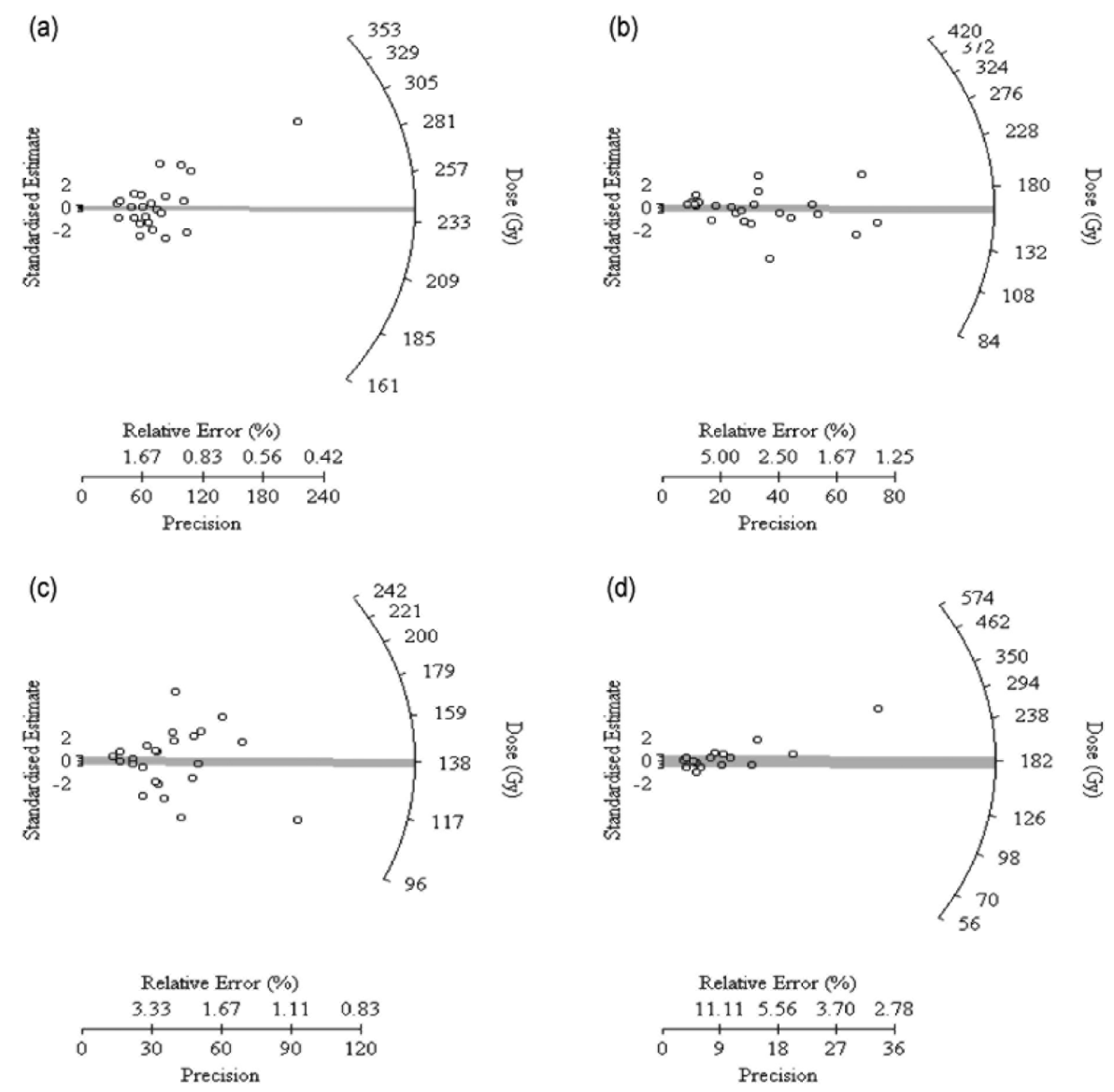

Fig. 5. Radial plots of samples: (a) APO01, (b) APO02, (c) KEN01, and (d) RGE01 showing the distribution of aliquots with their precisions. Optical ages were derived from the weighted mean $D_{e}$ using the central age model of Galbraith et al. (1999). Statistically concordant aliquots at the $2 \sigma$ confidence level are within \pm 2 units on the y-axis (shades).

parallel to coastlines suggest their marine origin. These higher terraces are often expressed as flatcrested ridges or concordant summits at the foot of coastal mountains in Anglesea, Lorne, Gellibrand Lower and Princetown.

\section{OSL Chronology}

Samples were collected by driving $50 \mathrm{~mm}$ diameter PVC tubes into vertical sections of terrace sediments. The outer few centimeters were discarded in laboratory as far as paleodose evaluation is concerned. The 90$125 \mathrm{~mm}$ quartz fraction was extracted for dating using the procedures of Galbraith et al. (1999).

\section{Equivalent dose estimation}

A Single-Aliquot Regenerative-dose (SAR) protocol was used to determine equivalent doses $\left(D_{e}\right)$ (Murray and Roberts, 1998; Murray and Wintle, 2000). Small aliquots of $\sim 5-10$ grains were preheated at $220^{\circ} \mathrm{C}$ for $10 \mathrm{~s}$ and optically stimulated for $100 \mathrm{~s}$ at $125^{\circ} \mathrm{C}$ by either green-plus- blue $(420-550 \mathrm{~nm})$ light from a tungsten-halogen lamp (automated Risø TL-DA-12 apparatus) (Bøtter-Jensen and Duller, 1992) or blue $(470 \mathrm{~nm})$ light from a light-emitting diode array (automated Risø TL-DA-15 apparatus) (Markey et al., 1997; Bøtter-Jensen et al., 2000). Ultraviolet luminescence was detected using photomultiplier tubes with either a $7.5 \mathrm{~mm}$ Hoya U-340 filter (Risø TL-DA- 
Table 2. Dose rate data, $\mathrm{D}_{\mathrm{e}}$ estimates and optical ages from $\mathrm{T}-2$ terrace deposits

\begin{tabular}{|c|c|c|c|c|c|c|c|c|c|c|}
\hline \multirow[b]{2}{*}{$\begin{array}{c}\text { Sample } \\
\text { name }\end{array}$} & \multirow[b]{2}{*}{$\begin{array}{c}\text { Depth } \\
\text { (m) }\end{array}$} & \multirow[b]{2}{*}{$\begin{array}{l}\text { Water }^{a} \\
(\%)\end{array}$} & \multicolumn{3}{|c|}{ Radionuclide concentrations $^{\mathrm{b}}$} & & \multirow{2}{*}{$\begin{array}{l}\text { Cosmicray } \\
\text { radiation } \\
\left(\mathrm{Gy} \mathrm{Ka}^{-1}\right)\end{array}$} & \multirow{2}{*}{$\begin{array}{c}\text { Total } \\
\text { dose } \\
\text { rate } \\
\left(\mathrm{Gy} \mathrm{Ka}^{-1}\right)\end{array}$} & \multirow{2}{*}{$\begin{array}{l}\text { Equivalent } \\
\text { dose }^{\mathrm{g}}\end{array}$} & \multirow{2}{*}{$\begin{array}{l}\text { Optical } \\
\text { age } \\
\text { (ka) }\end{array}$} \\
\hline & & & $\begin{array}{c}\mathrm{K} \\
(\%)\end{array}$ & $\begin{array}{c}\text { Th } \\
\text { (ppm) }\end{array}$ & $\begin{array}{c}\mathrm{U} \\
(\mathrm{ppm})\end{array}$ & $\begin{array}{ll}\text { radiation }^{\mathrm{c}} \text { radiation }^{\mathrm{d}} \text { radiation }^{\mathrm{e}} \\
\left(\mathrm{Gy} \mathrm{Ka}^{-1}\right) & \left(\mathrm{Gy} \mathrm{Ka}^{-1}\right) \\
\left(\mathrm{Gy} \mathrm{Ka}^{-1}\right)\end{array}$ & & & & \\
\hline APO01 & 2.0 & $10 \pm 3$ & $0.49 \pm 0.02$ & $7.70 \pm 0.24$ & $1.28 \pm 0.10$ & $0.03 \pm 0.01 \quad 0.61 \pm 0.03 \quad 0.56 \pm 0.11$ & $0.15 \pm 0.02$ & $1.35 \pm 0.15$ & $>179$ & $>133 *$ \\
\hline APO02 & 0.7 & $15 \pm 5$ & $0.14 \pm 0.01$ & $6.06 \pm 0.19$ & $1.51 \pm 0.09$ & $\begin{array}{llll}0.03 \pm 0.01 & 0.37 \pm 0.03 & 0.42 \pm 0.08\end{array}$ & $0.19 \pm 0.02$ & $1.01 \pm 0.11$ & $162 \pm 10$ & $160 \pm 20$ \\
\hline KEN01 & 2.5 & $15 \pm 5$ & $0.92 \pm 0.04$ & $5.82 \pm 0.19$ & $1.81 \pm 0.12$ & $0.03 \pm 0.01 \quad 0.85 \pm 0.06 \quad 0.60 \pm 0.12$ & $0.14 \pm 0.01$ & $1.62 \pm 0.18$ & $139 \pm 9$ & $86 \pm 11$ \\
\hline RGE01 & 10.0 & $10 \pm 3$ & $0.18 \pm 0.01$ & $5.01 \pm 0.17$ & $1.33 \pm 0.13$ & $\begin{array}{llll}0.03 \pm 0.01 & 0.37 \pm 0.02 & 0.39 \pm 0.08\end{array}$ & $0.05 \pm 0.01$ & $0.84 \pm 0.10$ & $181 \pm 16$ & $217 \pm 31$ \\
\hline
\end{tabular}

a estimated time-averaged moisture content, base on measured field water value (\% dry weight)

bobtained by INAA (Becquerel Laboratories, Mississauga, ON, Canada)

${ }^{c}$ assumed intemal alpha dose rate

derived from INAA radionuclide concentration measurements using the conversion factors of Adameic and Aitken (1998), corrected for attenuation by water and beta attenuation

'derived from INAA radionuclide concentration measurements using the conversion factors of Adameic and Aitken (1998), corrected for attenuation by water

calculated using the equation of Prescott and Hutton (1994), based on sediment density, time-averaged depth and site latitude, longitude and altitude

${ }^{g}$ central age model (Galbraith et al. 1999) (except for APO01 and STR01, where the minimum age model was used), including $\mathrm{a} \pm 2 \%$ systematic uncertainty associated with calibration of the laboratory beta-source

*saturated: Equivalent dose calculated using minimum age model (Galbraith et al. 1999)

15) or two $3 \mathrm{~mm}$ Hoya U-340 filters (Risø TL-DA-

12). Samples were then given applied doses using calibrated ${ }^{90} \mathrm{Sr} /{ }^{90} \mathrm{Y}$ beta-sources and re-stimulated to record their regenerative OSL signals. OSL sensitivity changes in the quartz crystals between the natural and regenerative cycles were monitored after each optical stimulation using test-doses of 1-2 Gy following a $160^{\circ} \mathrm{C}$ cut-heat. Preheat tests were carried out on twelve 100 grain aliquots of each sample by holding three aliquots at one of four preheat temperatures $(160,200,240,2801 \mathrm{C})$ for $10 \mathrm{~s}$. The resultant flat plateau indicated no significant thermal transfer in the samples. They also displayed little appreciable radiative recombination in recuperation tests. These experiments, including recycling tests using duplicate regenerations of known dose, confirmed the reproducibility of the laboratory-induced luminescence signals. Output from the Risø apparatuses was analysed using TL-HR23 Data Reader version 8.0 and Analyst version 2.12 software. OSL signals were measured for $100 \mathrm{~s}(250$ $\times 0.4 \mathrm{~s}$ channels) and integrated over the first $4.8 \mathrm{~s}$ of illumination with the final $20 \mathrm{~s}$ converted to the equivalent number of channels over $4.8 \mathrm{~s}$ and subtracted as background. The OSL data were corrected for any sensitivity changes and dose-response curves constructed using two to six regenerative dose points, depending on the magnitude of the $D_{e}$ of the samples. $D_{e}$ was obtained from the intercept of the regenerated doseresponse curve with the natural luminescence intensity. Weighted mean $D_{e}$ and their uncertainties were calculated using the central age model of Galbraith et al. (1999).

\section{Dose rate measurements}

$\mathrm{K}$, Th, and $\mathrm{U}$ concentrations were measured using Instrumental Neutron Activation Analysis (INAA) by Becquerel Laboratories, Mississauga, Ontario, Canada. Beta and gamma dose rates were derived from INAA radionuclide concentration measurements using the conversion factors of Adameic and Aitken (1998). Internal alpha dose rates were assumed to be $0.03 \pm$ $0.01 \mathrm{~Gy} \mathrm{ka}^{-1}$ (Bowler et al., 2003). Cosmic-ray dose rates were determined from established equations (Prescott and Hutton, 1994) based on sediment density, time-averaged depth and site latitude, longitude and altitude. Moisture contents of the sediments were considered representative of long-time averages based on measured field water value ( $\%$ dry weight), and used to correct attenuation of $\mathrm{b}$ and $\mathrm{g}$ rays by water (Aitken, 1998). The dose rates, equivalent dose 


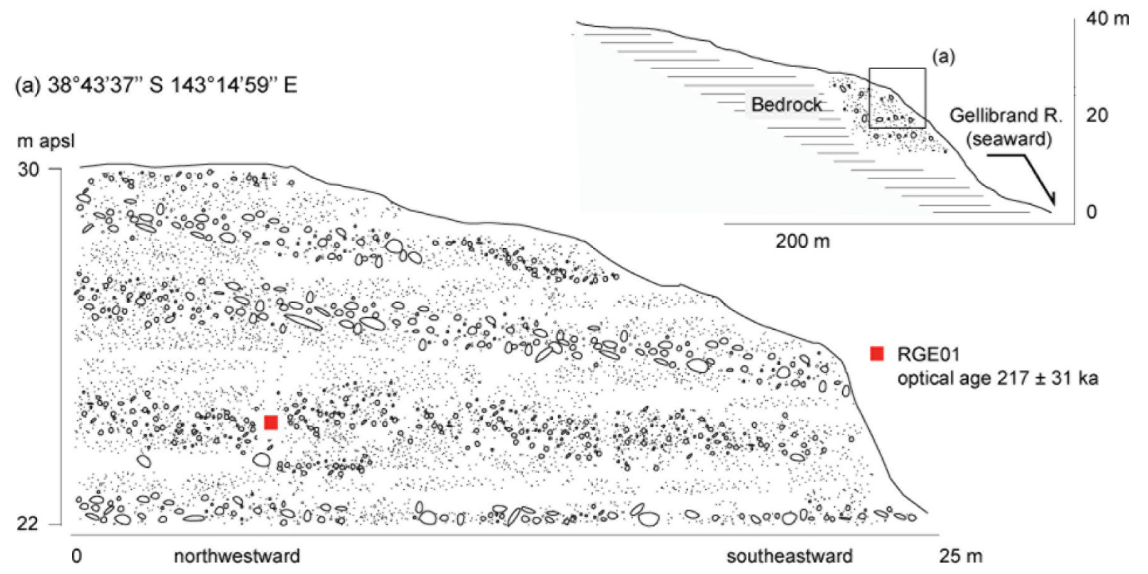

(b) $38^{\circ} 45^{\prime} 36^{\prime \prime} \mathrm{S} 143^{\circ} 39^{\prime} 49^{\prime \prime} \mathrm{E}$

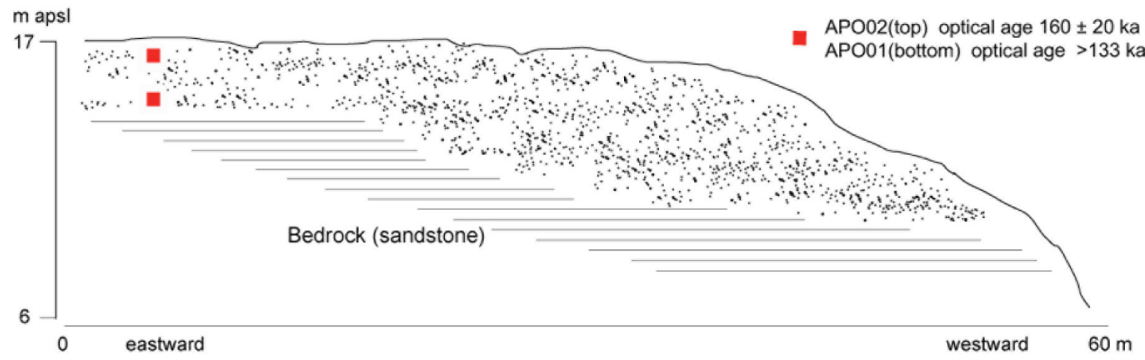

Fig. 6. Cross-sections of T-2 terraces in Glenaire (a) and Apollo Bay (b) showing sampling points and estimated optical ages.

estimates and the obtained optical ages are presented in Table 2. These are the relative standard deviations of the $\mathrm{D}_{\mathrm{e}}$ distributions after accounting for measurement uncertainties associated with each aliquot. The ages represent sensible internal consistency with relative stratigraphic succession. The single aliquot $D_{e}$ distributions are displayed in radial plots (Fig. 5). These show the distribution of aliquots with their precisions. Statistically concordant aliquots at the 2ó confidence level are within \pm 2 units on the $y$-axis (shades).

\section{Results}

Four samples were taken from deposits overlying bedrock surfaces of T-2 terraces. RGE01 was collected in Gellibrand Lower (38 $43^{\prime} 37^{\prime \prime} \mathrm{S}, 143^{\circ} 15^{\prime} 59^{\prime \prime} \mathrm{E}$ ) (Fig. 6a). Although the sampling site is a few kilometers away from sea, thalassostatic terraces are occurred continuously from Princetown to Gellibrand Lower along the Gellibrand River. Terraces along the river are genetically coeval with marine terraces in the coastlines corresponding to eustatic sea level changes during the late Quaternary (Fairbridge, 2005). The current large estuary is likely to have formed by the development of longshore bar and aeolian dunes in Princetwon beach. The sedimentary unit of RGE01 is composed of a number of distinct layers including grey silt, fine sand, oxidised yellow coarse sand, granules and pebbles. Sorting of grains in each layer is good, and beddings decline gradually toward Gellibrand River. The thickness of sediments is $\sim 8$ meters. The obtained optical age of RGE01 is $217 \pm 31$ ka BP. The age of RGE01 is well assigned to the MIS (marine oxygen isotope stage) 7 around ca. 190-240 ka BP, although there may be some influence from fluvial depositional thickening.

APO01 and APO02 were collected from estuarine 


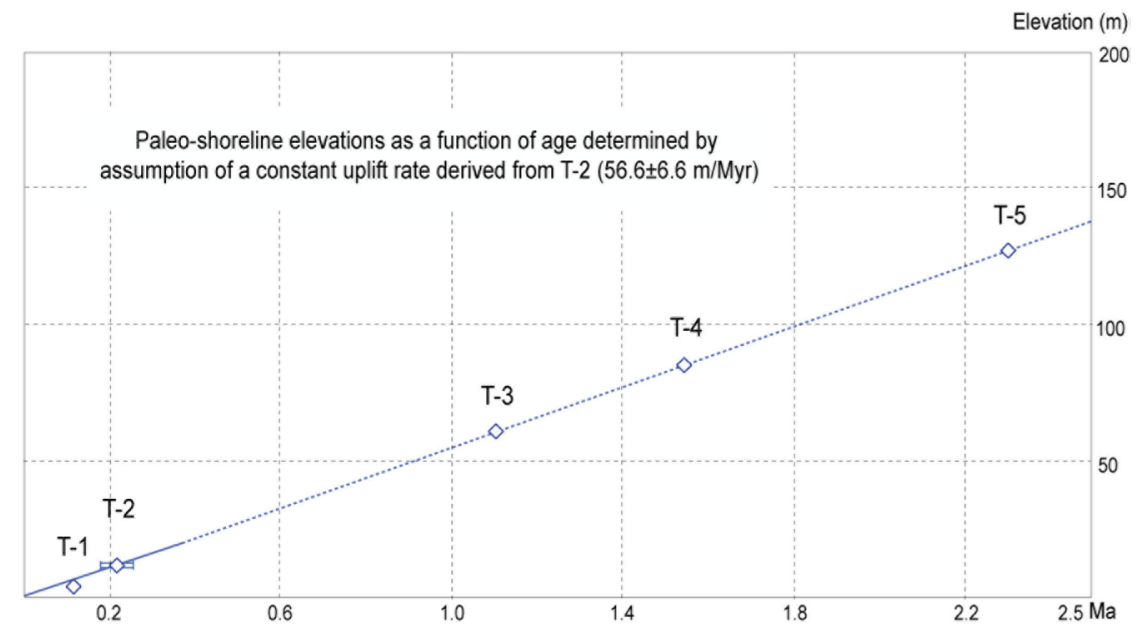

Fig. 7. Estimation of uplift rate derived from T-2 assuming by consistent uplift rate during the Quaternary (MIS 7:190-240 ka, $12 \mathrm{~m}$ apsl of inner edge elevation, $0 \mathrm{~m}$ for paleo-sea level). T-5 is situated at the boundary of Pliocene and Quaternary in the graph.

clay and clayey sand in Apollo Bay (38 45'36"S, $143^{\circ} 39^{\prime} 49^{\prime \prime}$ ) (Fig. 6b). The Early Cretaceous feldspathic and lithic sandstone underlies the 3 m-thick sediments, and the samples were selected from different layers of the same outcrop in depth of 2 and $0.7 \mathrm{~m}$, respectively. In the sediment unit, a brown to yellow brown clay sediment layer (lower layer) turn to top brown black to black silt and silty sand (upper layer). The basement elevation at the sampling site is $14 \mathrm{~m}$ apsl. APO01 and APO02 samples yielded the burial ages of $>133 \mathrm{ka} \mathrm{BP}$ and $160 \pm 20 \mathrm{ka}$ BP, respectively. The OSL ages and geomorphic set around the sampling site suggest that they were deposited in a fluvial origin by the meandering Barham River and its distributaries. However, the obtained ages provides a temporal constraint for the formation age of the $\mathrm{T}-2$ terrace in Apollo Bay. If assumed that the T-2 terrace underlying APO01 and APO02 was formed corresponding to the former interglacial from deposition of the sediments, it is possibly considered that the T-2 terrace corresponds to a substage of the penultimate interglacial time (MIS 7).

KEN01 was obtained in the mouth of Kennett River $\left(38^{\circ} 39^{\prime} 58^{\prime \prime} \mathrm{S}, 143^{\circ} 51^{\prime} 45^{\prime \prime} \mathrm{E}\right)$. The sediments are underlain by a planar bedrock surface ( $13.5 \mathrm{~m}$ apsl) of the Early Cretaceous sandstone, which is mostly composed of deoxidized grey clayey sand with rich organic materials. The thickness of sedimentary unit is 3 meters. The optical age of KEN01 was obtained as $86 \pm 11 \mathrm{ka}$ BP. Sea level around 80-90 ka BP was $\sim 30$ $\mathrm{m}$ below present sea level (MIS 5a substage), suggesting the sediment was deposited in a fluvial origin after the formation of the T-2 terrace. This is supported as well by the exceptionally planar bedrock surface with centimeter-scale relief underlying KEN01. The uppermost of the bedrock is deeply weathered, implying that the T-2 represents a longer period of exposure and erosion before deposition of the sediment.

Based on the interpretation with the estimated optical ages and the stratigraphic order, it is proposed that the formation time of the T-2 terrace confines the penultimate interglacial (MIS 7, 190-240 ka BP), then likely formation ages of the T-1 terrace is the last interglacial time (MIS 5e, $125 \mathrm{ka}$ BP). These formation ages have been used for calculating the Quaternary uplift rate of the Otway coast with the estimated paleo-shoreline elevations of each terrace.

\section{Discussion}

\section{Quaternary uplift rate}

Information on the Quaternary sea level records is essential in order to calculate uplift rate of a coastal region. In the Australian continent, terrestrial sea level 


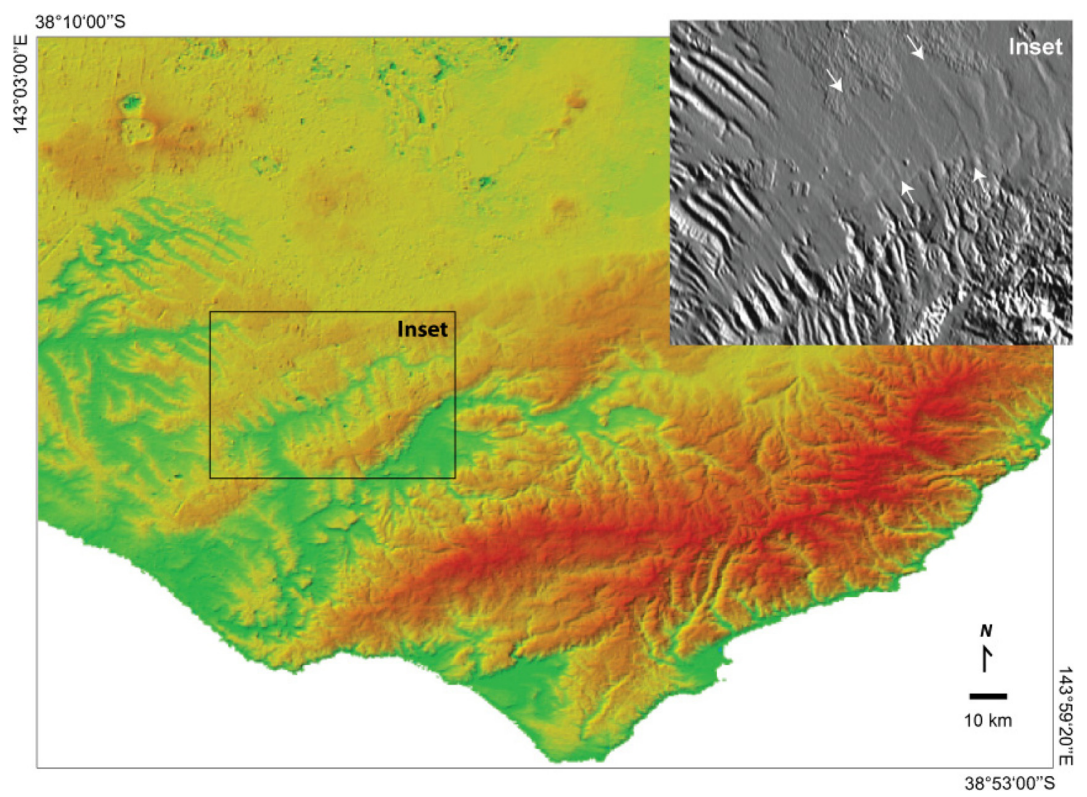

Fig. 8. Shaded topography of the study area derived from ASTER GDEM. The insect is represented with $5 \mathrm{~m}$ amplitude (white arrows) in the Pliocene Strandplains (Sandiford, 2003a).

records of the middle-late Quaternary are extensively well preserved as high-stand marine successions in the Coorong Coastal Plains, South Australia. From these successions, sea level for MIS 7 was estimated from -6 to $0 \mathrm{~m}$ with assumption of $+2 \mathrm{~m}$ reference level of MIS 5e stage (Murray-Wallace, 2002). It is assumed herein that the sea level at MIS 7 stage was as high as present level. The age-altitude curve with the uplift rate derived from the T-2 is shown in Fig. 7. The formation age of the T-2 terrace has been assigned as MIS 7 stage (190-240 ka BP), and the elevation of inner edge measured in field is $12 \mathrm{~m}$ apsl. As a result, the calculated uplift rate is $56.6 \pm 6.6 \mathrm{~m} \mathrm{Myr}^{-1}$ during the late Quaternary, higher terraces above the T-2 are located in time of the early Pleistocene on the graph with assumption of a constant uplift during the entire Quaternary.

\section{Stratigraphic relationship with Pliocene strandlines}

Pliocene strandlines are extensively well developed in the northwestern flanks of the Otway Ranges (Fig. 8), and they provide constraints on the late Neogene tectonic activity. The geomorphic expression of these strandlines has been greatly accentuated by erosional landsculpting resulting in the development of a dramatic trellised drainage net (Sandiford, 2003a). Profiles along strandlines rise from less than $120 \mathrm{~m}$ to up to $280 \mathrm{~m}$ on the northwestern flanks, stepping over a series of small faults and monoclinal flexures, for example the Simpson and Ferguson Hill anticlines bound by an east-northeast-trending array of en échelon faults. The maximum elevation of the preserved strandlines coincides with a prominent break in slope at $\sim 230-280 \mathrm{~m}$. Sandiford (2003a) interpreted that this break in slope almost reflects the position of the Pliocene coastline (Fig. 9). The depositional time of the strandlines were estimated as the early-middle Pliocene by Wallace et al. (2005). Strontium isotope ages from well-preserved molluscan assemblages of the strandplain successions indicate that the earliest sediments were deposited above the late Miocene unconformity at around 5.8 $\pm 0.2 \mathrm{Ma}$ (latest Miocene). The youngest exposed strandplain sediments were deposited during the early Quaternary time (ca. 2.0 Ma).

Estimates for mid-Pliocene sea levels range from 10 to $40 \mathrm{~m}$ above sea level (Lisiecki and Raymo, 2005; Dwyer and Chandler, 2009), and recently a numerical 


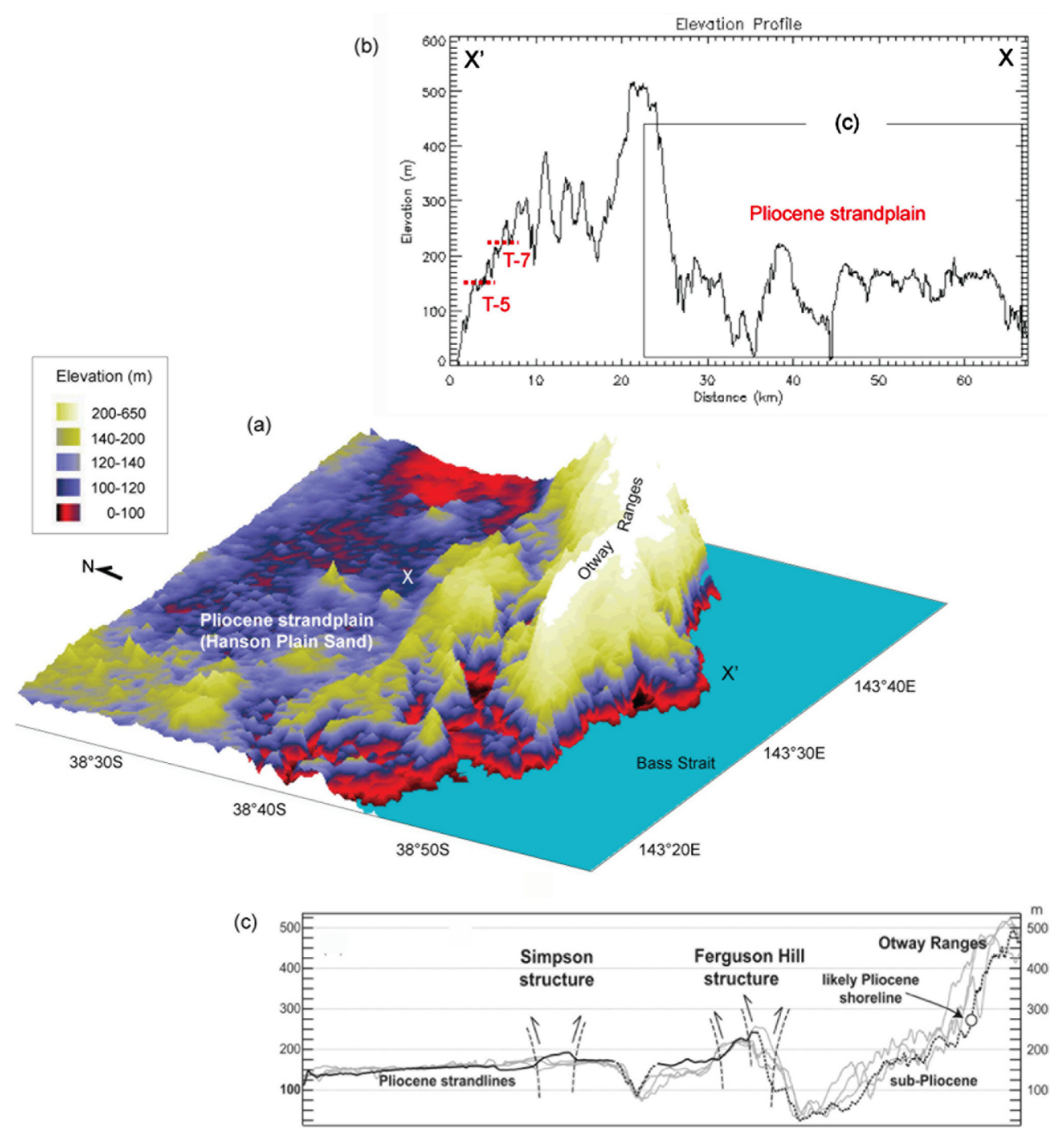

Fig. 9. Correlation between T-5 and Pliocene strandplain (Hanson Plain Sand) cross the Otway Ranges. (a) Three-dimensional topography of the Pliocene strandplains and the Otway Ranges, (b) T-5 terraces and Low strandplain are corresponded in the profile cross the ranges, and (c) the suggested position of the Pliocene shoreline on the ancestral range front by Sandiford (2003a).

model (Raymo et al., 2011) predicted elevation of a $+14 \mathrm{~m}$ eustatic change with adjustment of glacial isostatic effects up to the middle Pliocene (ca. $3 \mathrm{Ma}$ ). A value of $+14 \mathrm{~m}$ is adopted in this study for Pliocene eustatic signal, then implying that the northwestern side of the Otway Ranges has been experienced 216$264 \mathrm{~m}$ of post-Miocene (5.5 Ma) uplift. The elevation (at around $120 \mathrm{~m}$ ) and ages (2 Ma old) of the youngest strandplain in the northwestern side of the ranges correlate to those of the T-5 terrace in the southeastern side, suggesting that a tectonic uplift has been essentially uniform across the ranges since the Pliocene. Based on this correlation, an uplift rate for the Pliocene has been calculated, as illustrated in Fig. 10. In this graph, it is clearly seen that there is a significant change of tectonic intensity between the Pliocene and the Quaternary.

\section{Changing Neogene tectonic activity}

A change of tectonic activity since Pliocene is certainly recognised based on the stratigraphic relationships between Quaternary marine terrace 


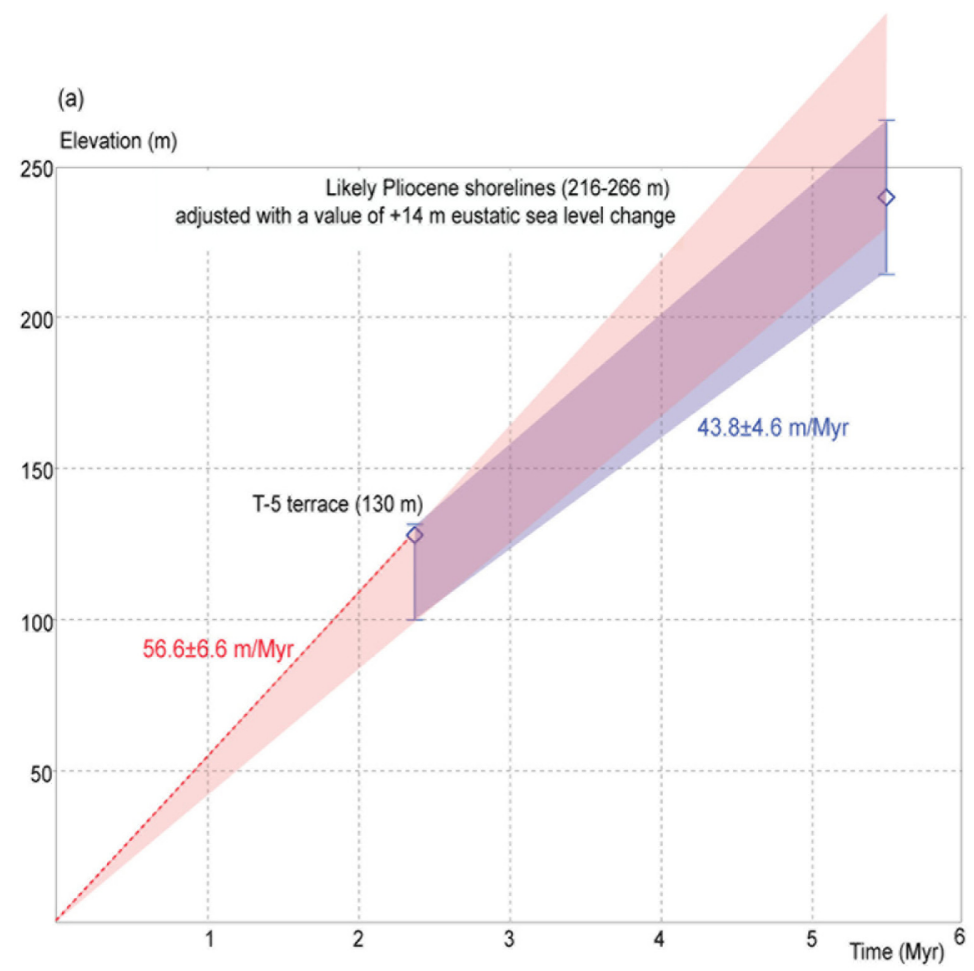

(b)

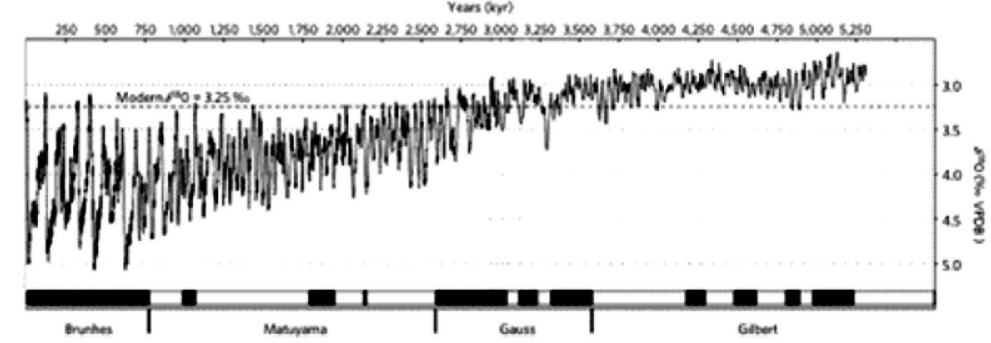

Fig. 10. (a) Inferred Pliocene uplift rate based on the correlation between Quaternary terraces and Pliocene strandplains. (b) Stack of globally distributed benthic $\delta^{18} \mathrm{O}$ records showing pattern of climate variability over past $5 \mathrm{Ma}$. Approximately, a variation of $0.1 \%$ of the $\delta^{18} \mathrm{O}$ corresponds to a variation of about $10 \mathrm{~m}$ of the sea level (Lisiecki and Raymo, 2005). With adjustment of glacial isostatic effects up to the middle Pliocene (ca. $3 \mathrm{Ma}$ ), a value of $+14 \mathrm{~m}$ for Pliocene eustatic signal (Raymo et al., 2011) is adopted in this study.

sequences and Pliocene strandlines. The uplift rate over the last $240 \mathrm{ka}$ records $56.6 \pm 6.6 \mathrm{~m} \mathrm{Myr}^{-1}$, likely to have been constant during the Quaternary, whereas the cumulative uplift rate since the Pliocene was estimated as $43.8 \pm 4.6 \mathrm{~m} \mathrm{Myr}^{-1}$. A similar observation was also suggested by an unconformable relationship between the Pliocene and Quaternary strandlines, implying either renewed Quaternary tectonism or eustatic factors, although the nature of the change is still arguable. Dickinson et al. (2002) suggested two successive pulses of tectonism in Southeast Australia since the Late Miocene. Of these two pulses Late Pliocene to Pleistocene uplift is less significant than late Miocene uplift and exhumation, although both events were initiated under the same stress regime. Similarly, Sandiford et al. (2004) noted that an emphasised neotectonic activity in Southeast Australia terminated in the late Miocene at around $5 \mathrm{Ma}$, followed by ongoing deformation, possibly at somewhat lower bulk strain rates since then. Coblentz et al. 
(1998) analysed the role of collisional forces generated by the Himalayan, New Guinea and New Zealand collision zones in balancing plate driving forces of ridge push and slab pull, with the SHmax aligning to a near-orthogonal direction in the vicinity of each of these collisional orogens (Sandiford et al., 2009). For instance, the convergence between the Pacific and Indo-Australian plates responsible of the South Alps collision zone in New Zealand is related to progressive changes in plate rotation poles in the period 10-5 Ma (Sandiford et al., 2004). As such, the intensified tectonic response during the Late Miocene (10-5 Ma) is well addressed in terms of the increase of the Australian intra-plate stress level due to the change of relative motion and increased forces at the boundary between the Australian and Pacific Plates (Walcott, 1998; Dickinson et al. 2002; Cande and Stock, 2004). The onset of renewed Quaternary tectonism in Southeast Australia is presumably attributed to an accumulative increase in stress level, although there is yet insufficient information to discuss time intervals and detailed causative factors.

\section{Conclusion}

Seven marine terraces elevated up to $220 \mathrm{~m}$ apsl have been mapped along the Otway coast, and the numerical formation age of the T-2 terrace at $12 \mathrm{~m}$ apsl has been assigned as MIS 7 stage (190-240 ka BP) using OSL dating method. The calculated uplift rate during the late Quaternary is $56.6 \pm 6.6 \mathrm{~m} \mathrm{Myr}^{-1}$, and the higher terraces above the T-2 are assigned in time of the early Pleistocene with assumption of a constant uplift during the Quaternary. A change of tectonic activity since the Pliocene is recognised based on the stratigraphic relationships between the Quaternary marine terraces and the Pliocene strandlines. The intensified tectonic response during the Late Miocene (10-5 Ma) is well addressed in terms of an increase of the Australian intra-plate stress level due to the change of relative motion and increased forces at the boundary between the Australian and Pacific plates.

\section{References}

Adameic, G. and Aitken, M., 1998, Dose-rate conversion factors: Update. Ancient TL, 16, 37-50.

Aitken, M.J., 1998, An Introduction to optical dating: The dating of Quaternary Sediments by the use of photonstimulated luminescence. Oxford University Press, Oxford, UK, $44 \mathrm{p}$.

Bøtter-Jensen, L. and Duller, G.A.T., 1992, A new system for measuring OSL from quartz samples. Nuclear Tracks and Radiation Measurements, 20, 549-553.

Bøtter-Jensen, L., Bulur, E., Duller, G.A.T., and Murray, A.S., 2000, Advances in luminescence instrument systems. Radiation Measurements, 32, 523-528.

Bowler, J.M., Johnston, H., Olley, J.M., Prescott, J.R., Roberts, R.G., Shawcross, W., and Spooner, N.A., 2003, New ages for human occupation and climatic change at Lake Mungo, Australia. Nature, 421, 837-840.

Brooke, B., 2001, The distribution of carbonate eolianite. Earth Science Reviews, 55, 135-164.

Cande, S.C. and Stock, J.M., 2004, Pacific-AntarcticAustralia motion and the formation of the Macquarie Plate. Geophysical Journal Internatinal, 157, 399-414.

Caputo, R., 2007, Sea-level curves: Perplexities of an enduser in morphotectonic applications. Global and Planetary Change, 57, 417-423.

Celerier, J., Sandiford, M., Hansen, D.L., and Quigley, M., 2005, Modes of active intraplate deformation, Flinders Ranges, Australia. Tectonics, 24, doi:10.1029/ 2004TC001679.

Claessens, L., Veldkamp, A., ten Broeke, E.M., and Vloemans, H., 2009, A Quaternary uplift record for the Auckland region, North Island, New Zealand, based on marine and fluvial terraces. Global and Planetary Change, 68, 383-394.

Coblentz, D., Zhou, S., Hillis, R., Richardson, R., and Sandiford, M., 1998, Topography, plate-boundary forces and the Indo-Australian intraplate stress field. Journal of Geophysical Research, 103, 919-931.

Davies, J.L., 1986, The coast. In Jeans, D.N. (eds.), Australia-a Geography, Vol. 1, the Natural Environment. Sydney University Press, Sydney, Australia, 222 p.

Demidjuk, Z., Turner, S., Sandiford, M., George, R., Foden, J., and Etheridge, M., 2007, U-series isotope and geodynamic constraints on mantle melting processes beneath the newer volcanic province in South Australia. Earth and Planetary Science Letters, 261, doi:10.1016/ j.epsl.2007.07.006.

Dickinson, J.A., Wallace, M.W., Holdgate, G.R., Gallagher, S.J., and Thomas, L., 2002, Origin and timing of the Miocene-Pliocene unconformity in southeast Australia. 
Journal of Sedimentary Research, 72, 317-332.

Dwyer, G.S. and Chandler, M.A., 2009, Mid-Pliocene sea level and continental ice volume based on coupled benthic $\mathrm{Mg} / \mathrm{Ca}$ palaeotemperatures and oxygen isotopes. Philosophical Transcations of the Royal Society, 367, doi:10.1098/rsta.2008.0222.

Fairbridge, R., 2005, Encyclopedia of coastal science. Earth and Environmental Science, 19, doi:10.1007/1-40203880-1 311.

Galbraith, R.F., Roberts, R.G., Laslett, G.M., Yoshida, H., and Olley, J.M., 1999, Optical dating of single and multiple grains of quartz from Jinmium rock shelter, Northern Australia: Part I, experimental design and statistical models. Archaeometry, 41, 339-364.

Gardner, T., Webb, J., Pezzia, C., Amborn, T., Tunnell, R., Flanagan, S., Merritts, D., Marshall, J., Fabel, D., and Cupper, M.L., 2008, Episodic intraplate deformation of stable continental margins: Evidence from Late Neogene and Quaternary marine terraces, Cape Liptrap, Southeastern Australia. Quaternary Science Reviews, 115.

James, N.P., Bone, Y., Carter, R.M., and Murray-Wallace, C.V., 2006, Origin of the late Neogene Roe plains and their calcarenite veneer: Implications for sedimentology and tectonics in the Great Australian Bight. Australian Journal of Earth Sciences, 53, 407-419.

Lisiecki, L.E. and Raymo, M.E., 2005, A PliocenePleistocene stack of 57 globally distributed benthic $\delta^{18} \mathrm{O}$ records. Paleoceanography, 20, doi:10.1029/2004PA001071.

Markey, B.G., Bøtter-Jensen, L., and Duller, G.A.T., 1997, A new flexible system for measuring thermally and optically stimulated luminescence. Radiation Measurements, 27, 83-89.

Murray, A.S. and Roberts, R.G., 1998, Measurement of the equivalent dose in quartz using a regenerative-dose single-aliquot protocol. Radiation Measurements, 29, 503-515.

Murray, A.S. and Wintle, A.G., 2000, Luminescence dating of quartz using an improved single-aliquot regenerativedose protocol. Radiation Measurements, 32, 57-73.

Murray-Wallace, C.V., 2002, Pleistocene coastal stratigraphy, sea-level highstands and neotectonism of the Southern
Australian passive continental margin-a review. Journal of Quaternary Science, 17, 469-489.

Prescott, J.R. and Hutton, J.T., 1994, Cosmic ray contributions to dose rates for luminescence and ESR dating: Large depths and long-term time variations. Radiation Measurements, 23, 497-500.

Quigley, M., Cupper, M., and Sandiford, M., 2006, Quaternary faults of southern Australia: Palaeoseismicity, slip rates and origin. Australian Journal of Earth Sciences, 53, 285-301.

Raymo, M.E., Mitrovica, J.X., O’Leary, M.J., DeConto, R.M., and Hearty, P.J., 2011, Departures from eustasy in Pliocene sea-level records. Nature Geoscience, 4, 328-332.

Sandiford, M., 2003a, Geomorphic constraints on the Late Neogene tectonics of the Otway Range, Victoria. Australian Journal of Earth Sciences, 50, 69-80.

Sandiford, M., 2003b, Neotectonics of Southeastern Australia: Linking the Quaternary faulting record with seismicity and in situ stress. In Hillis, R.R. and Muller, D. (eds.), Evolution and dynamics of the Australian Plate. Geological Society of Australia, Special Publication, NY, USA, 101-113.

Sandiford, M., Quigley, M., de Broekert, P., and Jakica, S., 2009, Tectonic framework for the Cainozoic cratonic basins of Australia. Australian Journal of Earth Sciences, 56, doi:10.1080/08120090902870764.

Sandiford, M., Wallace, M., and Coblentz, D., 2004, Origin of the in situ stress field in south-eastern Australia. Basin Research, 16, 325-338.

Shoemaker, E.M. and Uhlherr, H.R., 1999, Stratigraphic relations of australites in the port Campbell Embayment, Victoria. Meteoritics and Planetary Science, 34, 369-384.

Walcott, R.I., 1998, Modes of oblique compression: Late Cenozoic tectonics of the South Island of New Zealand. Reviews of Geophysics, 36, 1-26.

Wallace, M.W., Dickinson, J.A., Moore, D.H., and Sandiford, M., 2005, Late Neogene strandlines of Southern Victoria: A unique record of eustacy and tectonics in Southeast Australia. Australian Journal of Earth Sciences, 52, 277-295. 